3. The large-particle count procedure indicated a rapid decrease in the number of particles present over parturition. It is suggested that this was the result of a rapid decrease in the number of particles other than mitochondria occurring simultaneously with a smaller increase in mitochondrial numbers.

4. Interrelationships between ribonucleic acid, deoxyribonucleic acid, tissue nitrogen, succinic oxidase and the large-particle counts are discussed.

We are greatly indebted to the Agricultural Research Council for an expenses grant to one of us (A.L.G.).

\section{REFERENCES}

Agrell, I. (1955). Exp. Cell Res. 8, 232.

Allard, C., Mathieu, R., Lamirande, G. de \& Cantero, A. (1952). Cancer Res. 12, 407.

Altmann, S. M. \& Crook, E. M. (1953). Nature, Lond., 171, 76.

Bonner, W. D. (1955). In Methods in Enzymology, vol. 1. Ed. by Colowick, S. P. \& Kaplan, N. O. New York: Academic Press Inc.

Brody, S. \& Nisbet, R. N. (1938). Res. Bull. Mo. agric. Exp. Sta. no. 285.

Cox, W. M. jun. \& Mueller, A. J. (1937). J. Nutr. 13, 249.

Cunningham, I. J. (1931). Biochem. J. 25, 1267.

Dmochowski, L. \& Strickland, L. H. (1953). Brit. J. Cancer, 7, 250.
Folley, S. J. \& French, T. H. (1949). Biochem. J. 45, 117. Gavosto, F. \& Moyson, F. (1953). Experientia, 9, 263.

Glock, G. E. \& McLean, P. (1954). Biochem. J. 56, 171.

Greenbaum, A. L. \& Slater, T. F.(1957a). Biochem.J. 66, 148.

Greenbaum, A. L. \& Slater, T.F. $(1957$ b). Biochem.J.66, 155.

Greenbaum, A. L., Slater, T. F. \& Reid, E. (1955). Nature, Lond., 175, 506.

Hirade, J. \& Hayashi, T. (1953). J. Biochem., Tokyo, 40, 461.

Howe, A., Richardson, K. C. \& Birbeck, M. S. C. (1956). Exp. Cell Res. 10, 194.

Jeffers, K. R. (1935). Amer. J. Anat. 56, 257.

Moore, R. O. \& Nelson, W. L. (1952). Arch. Biochem. Biophys. 36, 178.

Schneider, W. C. (1956). In Proc. 3rd Int. Congr. Biochem., Brussels. New York: Academic Press Inc.

Schneider, W. C. \& Hogeboom, G. H. (1950). J. biol. Chem. $183,123$.

Schneider, W. C. \& Potter, V. R. (1943). J. biol. Chem. 149, 217.

Shelton, E., Schneider, W. C. \& Striebich, M. J. (1953). Exp. Cell Res. 4, 32.

Thomson, J. F. \& Mikuta, T. (1954). Arch. Biochem. Biophys. 51, 487.

Thomson, J. F. \& Moss, E. M. (1955). Cancer, N.Y., 8, 789.

Tuba, J., Orr, P. F. \& Wiberg, G. S. (1955). Canad. J. Biochem. Physiol. 33, 904.

Underwood, E. J. (1956). In Trace Elements in Human and Animal Nutrition. New York: Academic Press Inc.

Weatherford, H. L. (1929). Amer. J. Anat. 44, 199.

\title{
Studies on Pituitary Adrenocorticotropin
}

\section{OXIDATION-REDUCTION PROPERTIES OF THE HORMONE*}

\author{
BY M. L. DEDMAN, T. H. FARMER AND C. J. O. R. MORRIS \\ Department of Experimental Biochemistry, London Hospital Medical School, London, E. 1
}

\section{(Received 27 August 1956)}

It is generally accepted that the biological activity of the pituitary adrenocorticotropic hormone (corticotropin, ACTH) is unstable under oxidizing conditions. For example, Dixon, Moore, StackDunne \& Young (1951) have advocated the use of anti-oxidants to diminish oxidative inactivation during extraction and purification of the hormone, and the practice has often been adopted by later workers. No quantitative data on the subject are, however, available.

The first evidence that the oxidation process may be reversible, at least in part, was provided by Kuehl, Meisinger, Brink \& Folkers (1953). These workers showed that corticotropin B, a highly active preparation made by partial peptic hydrolysis of purified pituitary extracts, could be oxidized by

* Part 1: Cortis-Jones, Crooke, Henly, Morris \& Morris (1950). the action of oxygen in the presence of ferric iron, to a product which was inactive in the ascorbic acid-depletion bioassay. The biological activity of the product could be restored by several days' contact with hydrogen sulphide. Attempts in several laboratories to repeat the reductive reactivation of oxidized hormone under the conditions advocated by Kuehl et al. (1953) have, however, been unsuccessful (Dixon \& Stack-Dunne, 1955).

The observations of Kuehl et al. (1953) are of interest from both the chemical and biological standpoints. First, it is generally agreed that the best corticotropin preparations now available contain no detectable sulphydryl groups, so that there is no obvious chemical explanation of the oxidation-reduction property. Secondly, the presence of an oxidation-reduction centre may also be of importance for the biological function of a 
hormone which controls an oxidative process, the oxidation of cholesterol in the adrenal cortex to $\mathrm{C}_{19}$ and $\mathrm{C}_{21}$ precursors of the adrenal hormones.

The present work has been concerned with the determination of the optimum conditions for the oxidation and reduction of corticotropin. Some observations on the nature of the oxidationreduction centre in the hormone are reported. A preliminary account of part of this work has already been published (Dedman, Farmer \& Morris, 1955).

\section{EXPERIMENTAL}

\section{Bioassay methods}

Adrenocorticotropic potency has been measured by the adrenal ascorbic acid-depletion method of Sayers, Sayers \& Woodbury (1948) with minor modifications (Morris, 1951).

The particular corticotropin preparation used for chemical treatment was always bioassayed in the untreated state, together with the treated material, so that any change in biological potency brought about by the chemical treatment can be expressed as a percentage of the initial potency. The absolute potencies of many of the untreated preparations assayed against international standard corticotropin are also given.

The values given in Tables 2-4 are the best estimates of potency, the confidence limits of the estimate at $P 0.95$, calculated according to Pugsley (1946), being given in parentheses.

\section{Reagents}

Analytical grade acetone was dried over anhydrous $\mathrm{K}_{2} \mathrm{CO}_{3}$ for $24 \mathrm{hr}$. and redistilled, the fraction of b.p. $56-57^{\circ}$ being collected. Analytical grade acetic acid (2 1.) was mixed with water $(50 \mathrm{ml}$.) and was boiled under reflux for $3 \mathrm{hr}$. The product was distilled through a $30 \mathrm{~cm} . \times 2 \mathrm{~cm}$. fractionating column packed with glass Fenske spirals and the fraction of b.p. 117-118 ${ }^{\circ}$ was collected. Ether (analytical grade) was freed from peroxides immediately before use by passage through a $20 \mathrm{~cm} . \times 2.5 \mathrm{~cm}$. column packed with $\mathrm{Al}_{2} \mathrm{O}_{3}$ (grade H, P. Spence and Co., Widnes).

Oxycellulose. This, with $10 \%$ carboxyl content, was obtained from the Tennessee Eastman Co., Kingsport, Tenn., U.S.A. It was purified immediately before use by the method of Astwood, Raben, Payne \& Grady (1951) by washing with $\mathrm{N} \cdot \mathrm{HCl}$ for $10 \mathrm{~min}$., followed by water and finally with $0 \cdot 1 \mathrm{~N}$-acetic acid for $10 \mathrm{~min}$.

Resins. Cation-exchange resin Amberlite XE-97, 200400 mesh (Chas. Lennig and Co., 18 York Buildings, London, W.C. 2), is a finely divided preparation of the carboxylic acid resin Amberlite IRC-50, and is also chemically identical with Amberlite XE-64. It was treated according to the method of Hirs, Moore \& Stein (1953) to remove soluble and very fine material and was subsequently dried to constant weight over silica gel in vacuo. The anion-exchange resins Amberlite IR-4B and Amberlite IRA-400, 60-100 mesh (Chas. Lennig and Co.), were treated in sequence with $2 \mathrm{~N}-\mathrm{HCl}$, water and $2 \mathrm{~N}-\mathrm{Na}_{2} \mathrm{CO}_{3}$ for three successive cycles, and were stirred for $30 \mathrm{~min}$. with each reagent. The resins were finally converted into the acetate forms by treatment with $2 \mathrm{~N}$-acetic acid. Dowex $50 \times 8,200-400 \mathrm{mesh}$, and Dowex 50 × 16, 60-100 mesh, cation-exchange resins (Dow Chemical Co., Midland, Mich., U.S.A.) were treated with
$4 \mathrm{~N}-\mathrm{HCl}$ and hot $\mathrm{N}-\mathrm{NaOH}$ to remove soluble material according to the method of Moore \& Stein (1951). Dowex $2 \times 8,60-100 \mathrm{mesh}$, anion-exchange resin (Dow Chemical Co.) was treated similarly to Amberlite IR-4B.

\section{Preparation of crude corticotropin}

The corticotropin preparations used were prepared from the anterior lobes of pig pituitary glands by minor modifications of published methods. Because of the wide variations in yields and potencies reported in the literature, a detailed description of the preparation is appended.

Whole pig pituitary glands, stored in anhydrous acetone, were received in the laboratory within five days of the death of the animal. The glands were stored for a further $24 \mathrm{hr}$. in fresh anhydrous acetone and the anterior lobes separated. These were thoroughly homogenized with anhydrous acetone in a high-speed blender and the homogenate was centrifuged. The precipitate was dried in vacuo. The dry powder assayed at 0.2-0.3 i.u./mg. Experience has shown that it is not possible to obtain high-potency preparations from a pituitary-gland powder assaying less than $0 \cdot 2$ i.u. $/ \mathrm{mg}$.

The pituitary powder was extracted with acetic acid by the method of Payne, Raben \& Astwood (1950) or the method of Dedman, Farmer, Morris \& Morris (1952). Both methods give products with potencies of $1-1 \cdot 8 \mathrm{i} . \mathrm{u}$./mg. It is particularly important that the acetic acid used should be freed from trace amounts of acetic anhydride as described under Reagents. The ether precipitate should be very thoroughly washed free from acetic acid with anhydrous acetone and dried in vacuo over silica gel.

Purification with oxycellulose. This step was carried out according to the procedure of Astwood et al. (1951). The optimum amount of oxycellulose required per unit weight of crude corticotropin varies with different preparations of the latter and can only be found from trial experiments. The ratio appears to be quite reproducible for the same preparations of corticotropin and oxycellulose. The biological activities of oxycellulose concentrates prepared in this laboratory have been in the range 30-70 i.u./mg. but have seldom been less than $\mathbf{4 0}$ i.u./mg.

Ion-exchange chromatography. The method used was a modification of that of White \& Fierce (1953). The purified Amberlite XE-97 resin (20 g.) was mixed with $\mathrm{N}-\mathrm{NaOH}$ (184 ml.) and $\mathrm{m}-\mathrm{NaCl}(20.4 \mathrm{ml}$.$) , stirred for 1 \mathrm{hr}$. and allowed to stand for $48 \mathrm{hr}$. at room temperature. The $\mathrm{pH}$ of the supernatant was then $8 \cdot 3$. A column $30 \mathrm{~cm} . \times 2 \mathrm{~cm}$. was prepared by pouring the resin slurry into a suitable glass chromatographic tube in six equal portions. The column was then washed with 2-3 1. of $0 \cdot 1 \mathrm{M}-\mathrm{NaHCO}_{3}$. The $\mathrm{pH}$ of the effluent liquid was then identical with that of the $0.1 \mathrm{M}$ $\mathrm{NaHCO}_{3}$ wash liquid, 8.32. The upper $1-2 \mathrm{~cm}$. of the resin was gently stirred and allowed to settle slowly in order to produce a flat upper surface.

An oxycellulose concentrate of corticotropin $(100 \mathrm{mg}$.) was dissolved in water $\left(10 \mathrm{ml}\right.$.) and $0 \cdot 2 \mathrm{M}-\mathrm{NaHCO}_{3}(10 \mathrm{ml}$.) added dropwise with stirring. After a further $20 \mathrm{~min}$. stirring the mixture was centrifuged and the supernatant liquid transferred to the column. The flow rate was adjusted so that the solution entered the column during the course of about $2 \mathrm{hr}$. Chromatographic development was continued with $0 \cdot 1 \mathrm{M}-\mathrm{NaHCO}_{3}$ at a flow rate of $15 \mathrm{ml} / \mathrm{hr}$. Fractions $(3 \mathrm{ml}$.) were collected by means of an automatic fraction collector, each fraction being taken into a tube containing $0.05 \mathrm{ml}$. of acetic acid, in order to reduce the period during 
which the corticotropin was exposed to alkaline conditions. The ultraviolet absorption of each fraction was measured at $275 \mathrm{~m} \mu$ in $1 \mathrm{~cm}$. quartz cells with a Unicam SP. 500 spectrophotometer. Fig. 1 shows a typical separation obtained in this way.

Three well-defined components have been found. These appear to correspond with the corticotropin fractions $A_{1}$, $A_{2}$ and $A_{4}$ of Dixon \& Stack-Dunne (1955), obtained by chromatography on a similar ion-exchange resin at $\mathrm{pH} 6 \cdot 7$ and at a higher ionic strength. Accordingly their nomenclature has been adopted for these components.

Corticotropins $\mathrm{A}_{1}$ and $\mathrm{A}_{2}$ were obtained from the $\mathrm{NaHCO}_{3}$ solutions by a combination of ion-exchange desalting and oxycellulose adsorption.

In a typical experiment, $135 \mathrm{ml}$. of $0 \cdot 1 \mathrm{~m}-\mathrm{NaHCO}_{3}$ containing corticotropin $\mathrm{A}_{1}$ was adjusted to $\mathrm{pH} \mathrm{3.5}$ with concentrated $\mathrm{HCl}$ and passed through a $9 \cdot 8 \mathrm{~cm} . \times 1.3 \mathrm{~cm}$. column containing $7 \mathrm{~g}$. of Dowex $50 \times 16$ cation-exchange resin in the $\mathrm{H}$ form. The column was washed with $20 \mathrm{ml}$. of $0 \cdot 1 \mathrm{~N}$-acetic acid and $\mathrm{Cl}^{-}$ions were removed from the total effluent by passage through an $8 \cdot 3 \mathrm{~cm} . \times 1.3 \mathrm{~cm}$. column containing $4 \mathrm{~g}$. of Amberlite IR-4 B anion-exchange resin in the acetate form. The corticotropin in the chloride-free solution was adsorbed on to oxycellulose (150 mg.). Adsorption was complete after stirring for $20 \mathrm{hr}$. at room temperature. The oxycellulose was separated by centrifuging, washed with $0 \cdot 1 \mathrm{~N}$-acetic acid and the corticotropin eluted by shaking with $0.1 \mathrm{~N}-\mathrm{HCl}(3 \mathrm{ml}$.) for $1 \mathrm{hr}$. The oxycellulose was eluted with three further $1 \mathrm{ml}$. portions of $0 \cdot 1 \mathrm{~N}-\mathrm{HCl}$ for $2 \mathrm{~min}$. periods. The combined eluates were freed from $\mathrm{HCl}$ by passage through a $7.2 \mathrm{~cm} . \times 0.7 \mathrm{~cm}$. column of Dowex $2 \times 8$ anion-exchange resin (1.5 g.) in the acetate form and freeze-dried. The yield of corticotropin $A_{1}$, based on the ultraviolet absorption at $275 \mathrm{~m} \mu$ of the original solution, was $83 \%$. The recovery of biological activity has always been in close agreement with the weight recovery. The process of re-adsorption on oxycellulose described above

appears to improve considerably the stability of the product.

Biological activity. Preparations of corticotropin $A_{1}$ made by this procedure have a biological activity in the range 75-150 i.u./mg., depending mainly on the potency of the oxycellulose concentrate subjected to chromatography. The majority of the preparations used in this work had a potency greater than 90 i.u./mg. Corticotropin $A_{2}$ preparations have shown lower biological activities in the range 38-68 i.u./mg. Dixon \& Stack-Dunne (1955) also found lower potencies for the corresponding fractions. Rechromatography of corticotropins $A_{1}$ and $A_{2}$ under conditions similar to those employed for their separation has shown consistent behaviour and has confirmed that the resolution of the two components is essentially complete. The potencies and yields of the various fractions obtained in the course of a typical corticotropin preparation are given in Table 1.

The work described in this paper has been carried out either with oxycellulose concentrates (OC) or with corticotropin $A_{1}$. The existence of a reversible oxidation-reduction system has, however, been confirmed in corticotropin $A_{2}$, and in corticotropin preparations which had been partially hydrolysed with $\mathrm{HCl}$. The work of Kuehl et al. (1953) demonstrates the existence of a similar system in pepsinhydrolysed corticotropin.

\section{Table 1. Purification of corticotropin}

\section{Stage}

Acetone-dried anterior pituitary powder Crude corticotropin Oxycellulose concentrate Corticotropin $A_{1}$ Corticotropin $\mathbf{A}_{\mathbf{2}}$

\begin{tabular}{ll}
$\begin{array}{c}\text { Potency } \\
\text { (i.u./mg.) }\end{array}$ & \multicolumn{1}{c}{$\begin{array}{c}\text { Yield } \\
\text { (g.) }\end{array}$} \\
$0 \cdot 20-0 \cdot 30$ & 100 \\
& \\
$1 \cdot 0-1 \cdot 8$ & $10-11$ \\
$40-50$ & $0 \cdot 2-0 \cdot 3$ \\
$90-110$ & $0 \cdot 06-0 \cdot 1$ \\
$40-60$ & $0 \cdot 02-0 \cdot 04$
\end{tabular}

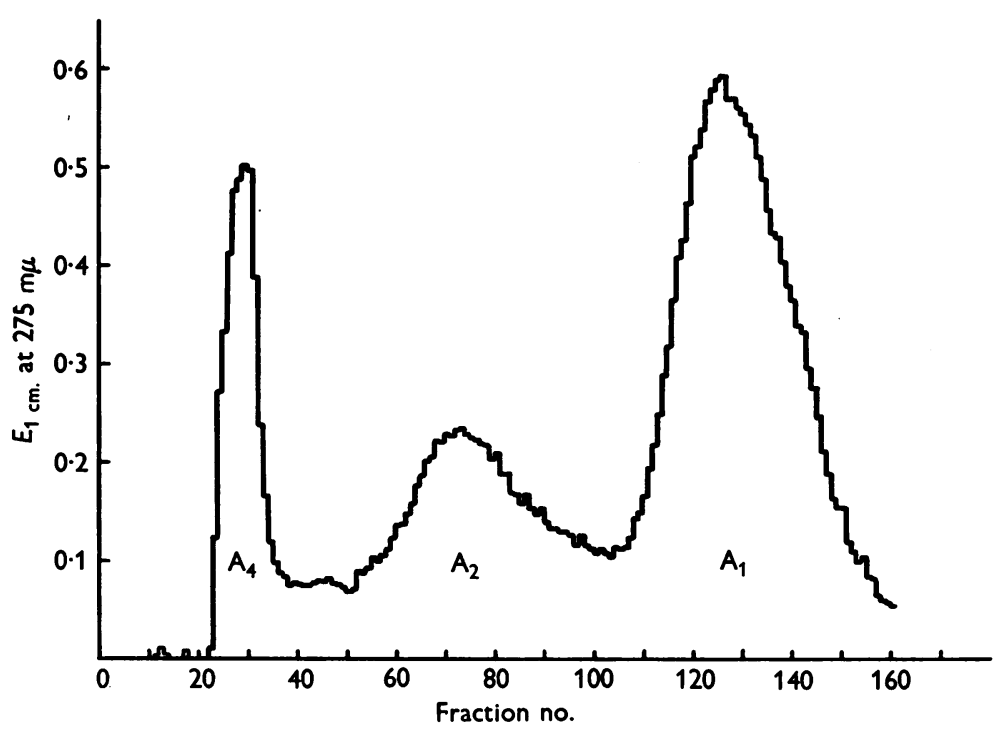

Fig. 1. Chromatography of an oxycellulose concentrate of corticotropin on Amberlite XE-97 cation-exchange resin, $0 \cdot 1 \mathrm{~m}-\mathrm{NaHCO}_{3}, 3 \mathrm{ml}$. fractions. 


\section{Amino acid determinations}

Hydrolysis of corticotropin preparations was carried out with redistilled $20 \% \mathrm{HCl}$ (constant b.p.) in sealed tubes for $18 \mathrm{hr}$. at $115^{\circ}$.

Quantitative estimation of the amino acids was carried out either by paper chromatography or by ion exchange. In the first method the amino acids were separated in a onedimensional chromatogram with the phenol-buffer, $\mathrm{pH} \mathrm{12,}$ or $m$-cresol-buffer, pH 8.4, system of McFarren (1951). Standards $(5,10$ and $15 \mu \mathrm{g}$.) of the particular amino acids to be estimated were chromatographed simultaneously on the same strip. After removal of the solvent the amino acid spots were developed with ninhydrin according to the method of Wael \& Cadavieco (1954). The coloured zones were cut out and the pigment was eluted with $50 \%(v / v)$ aqueous propan-1-ol. After removal of the filter paper, the optical densities of the solutions were determined at $570 \mathrm{~m} \mu$ in a Unicam SP. 600 spectrophotometer. The amount of amino acid in the portion of hydrolysate was determined by com. parison with standards which were chromatographed and developed simultaneously.

Complete amino acid analyses of a typical preparation of corticotropin $A_{1}$, and of peroxide-oxidized material prepared from it, were carried out with the method of ionexchange chromatography on Dowex $50 \times 8$ resin (Moore \& Stein, 1951), together with the improved photometric ninhydrin method of Moore \& Stein (1954). Unsatisfactory recoveries of arginine were obtained with the $15 \mathrm{~cm}$. columns described by these authors for the separation of the basic amino acids. Substitution of Dowex $50 \times 4$ resin for this purpose gave satisfactory results. Well-defined zones were obtained for the acidic and neutral amino acids on the $100 \mathrm{~cm}$. column of Dowex $50 \times 8$.

\section{Preparation of peroxide-oxidized corticotropin $A_{1}$}

Corticotropin $\mathrm{A}_{1}$ (9.8 mg.) was dissolved in water (1.5 ml.) and $0.05 \mathrm{~N}$-sodium acetate solution (3.5 ml.) added. A $6 \%$ $(\mathrm{w} / \mathrm{v}) \mathrm{H}_{2} \mathrm{O}_{2}$ solution was added in three $0.05 \mathrm{ml}$. portions at
$15 \mathrm{~min}$. intervals. After a further $45 \mathrm{~min}$. the reaction was stopped by the addition of $0.1 \mathrm{~N}-\mathrm{HCl}(1.4 \mathrm{ml}$.). Excess of $\mathrm{H}_{2} \mathrm{O}_{2}$ was removed by shaking with about $20 \mathrm{mg}$. of platinum black, until a negative starch-potassium iodide reaction was obtained. The platinum was removed by centrifuging and $0 \cdot 1 \mathrm{M}-\mathrm{NaCl}$ solution $(1 \mathrm{ml}$.) was added to the supernatant liquid. Sodium ions were removed from the solution by passage through a short column containing Dowex $50 \times 16$ cation-exchange resin (0.25 g.) in the hydrogen form, $\mathrm{Cl}^{-}$ions were exchanged for acetate with Amberlite IR-4 B anion-exchange resin in the acetate form $(0 \cdot 25 \mathrm{~g}$.). The oxidized corticotropin was adsorbed from the combined filtrate and washings on to acid-washed oxycellulose (50 mg.) during a period of $20 \mathrm{hr}$. Elution was carried out with $0 \cdot 1 \mathrm{~N}-\mathrm{HCl}\left(3 \times 2 \mathrm{ml}\right.$.); $\mathrm{Cl}^{-}$ions were exchanged for acetate with Amberlite IR-4 B acetate and the final eluate and washings freeze-dried. Yield, $7 \cdot 0 \mathrm{mg}$.

\section{Effect of $\mathrm{pH}$ on the oxidation of corticotropin $A_{1}$ by hydrogen peroxide}

A volume $(0.2 \mathrm{ml}$.) of a solution containing $1 \mathrm{mg}$. of corticotropin $A_{1} / \mathrm{ml}$. was mixed with $0.6 \mathrm{ml}$. of the appropriate buffer (ionic strength $I=0.084$ ) and $0.2 \mathrm{ml}$. of $0.2 \mathrm{M}-\mathrm{H}_{2} \mathrm{O}_{2}$ added. After $30 \mathrm{~min}$. at $25^{\circ}$, $1 \mathrm{ml}$. of $2 \mathrm{~N}$-acetic acid was added and the excess of $\mathrm{H}_{2} \mathrm{O}_{2}$ destroyed by the addition of a few milligrams of platinum black. After centrifuging to remove the platinum, the supernatant liquid was separated and a portion taken for bioassay. A volume $(1 \mathrm{ml}$.) was treated with cysteine hydrochloride $(20 \mathrm{mg}$.) and the mixture maintained at $78^{\circ}$ for $18 \mathrm{hr}$. After cooling, the solution was diluted for bioassay (Table 2, Expt. 2). The buffers used were (a) acetic acid-sodium acetate, $\mathrm{pH} 5 \cdot 0$; $(b)$ primary-secondary phosphate, pH 6.0, 7.0 and $8.0 ;$ (c) $\mathrm{NaHCO}_{3}-$ $\mathrm{Na}_{2} \mathrm{CO}_{3}, \mathrm{pH} 8 \cdot 5$.

Table 2. Oxidation of corticotropin

EDTA, ethylenediaminetetra-acetic acid; OC, oxycellulose concentrate; $A_{1}$, corticotropin $A_{1}$.

\begin{tabular}{cc}
$\begin{array}{c}\text { Initial potency } \\
\text { corticotropin } \\
\text { preparation } \\
\text { (i.u./mg.) }\end{array}$ \\
$\begin{array}{c}\text { Expt. } \\
\text { no. }\end{array}$ & $A_{1} 92(72-116)$ \\
1 & $A_{1} 116(75-179)$ \\
2 & \\
& \\
3 & $A_{1} 116(75-179)$ \\
4 & $A_{1} 98(62-154)$ \\
5 & $A_{1} 116(75-179)$ \\
6 & OC 49 (39-64) \\
7 & $A_{1} 116(75-179)$ \\
\hline
\end{tabular}

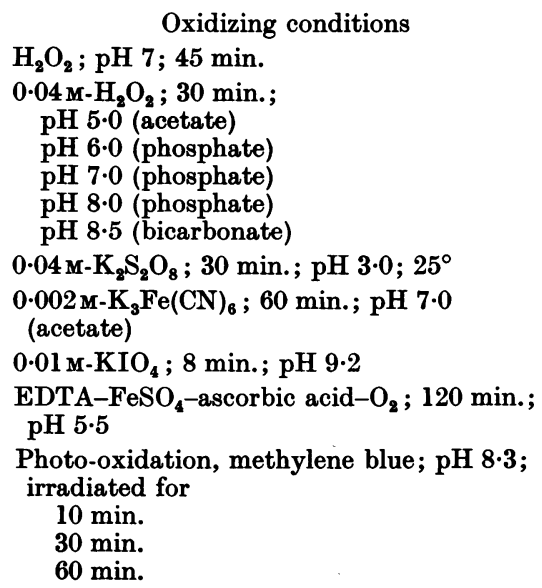

$\begin{array}{cc}\begin{array}{c}\text { Oxidized } \\ \text { potency } \\ \text { (\% of initial) }\end{array} & \begin{array}{c}\text { Reduced } \\ \text { potency } \\ \text { (\% of initial) } \\ 11(5-20)\end{array} \\ 108(72-165) \\ 33(17-61) & 110(72-181) \\ 22(15-30) & 108(81-138) \\ 26(13-50) & 81(73-90) \\ 17(10-25) & 78(46-129) \\ 9(7-15) & 64(30-144) \\ <4 & 11(8-18) \\ 19(12-27) & 94(49-178) \\ 7(5-11) & 10(7-13) \\ <35 & <35\end{array}$

$67(42-106)$

$<2$

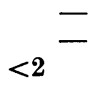




\section{Oxidation of corticotropin $A_{1}$}

Potassium peroxydisulphate. Corticotropin $\mathbf{A}_{1}$ $(0.54 \mathrm{mg}$.) in $0.1 \mathrm{~N}$-acetic acid $(0.5 \mathrm{ml}$.) was treated with $0.08 \mathrm{M}-\mathrm{K}_{2} \mathrm{~S}_{2} \mathrm{O}_{8}$ in $0.1 \mathrm{~N}$-acetic acid $(0.5 \mathrm{ml}$.) and the mixture kept at room temperature for $30 \mathrm{~min}$. Peroxydisulphate was removed by passage through a short column of Dowex $1 \times 8$ anion-exchange resin in the acetate form. Comparison of the ultraviolet absorption of the filtrate at 265 and $275 \mathrm{~m} \mu$ indicated that the specific tyrosine-tryptophan absorption band had disappeared. A volume (1 ml.) of the filtrate was treated with cysteine hydrochloride $\left(20 \mathrm{mg}\right.$.) at $78^{\circ}$ for $18 \mathrm{hr}$. and diluted for bioassay (Table 2, Expt. 3).

Potassium ferricyanide. Corticotropin $\mathbf{A}_{\mathbf{1}}$ $(0.47 \mathrm{mg}$.) was dissolved in $0.05 \mathrm{M}$-sodium acetate solution $(1 \mathrm{ml}$.) and the solution adjusted to $\mathrm{pH} \mathbf{7 \cdot 0}$. Potassium ferricyanide solution $(0.04 \mathrm{M}, 0.05 \mathrm{ml}$.) was added and the mixture kept at room temperature for $1 \mathrm{hr}$. The reaction was terminated by the addition of $2 \mathrm{~N}$-acetic acid $\left(1 \mathrm{ml}\right.$.), and $\mathrm{Fe}(\mathrm{CN})_{6}{ }^{3+}$ ions and any $\mathrm{Fe}(\mathrm{CN})_{6}{ }^{4+}$ ions formed were removed by passage through a short column of Dowex $2 \times 8$ anion-exchange resin in the acetate form. Portions of the oxidized solution, and of a portion reduced with cysteine hydrochloride $\left(20 \mathrm{mg}\right.$.) at $78^{\circ}$ for $18 \mathrm{hr}$., were diluted for bioassay (Table 2, Expt. 4).

Potassium periodate (cf. Dixon, 1956). Corticotropin $A_{1}(8.4 \mathrm{mg}$.) and histidine hydrochloride (4.64 mg.) were dissolved in water $(2 \cdot 1 \mathrm{ml}$.) and the $\mathrm{pH}$ of the mixture was brought to $9 \cdot 2$ by the addition of $0.2 \mathrm{M}-\mathrm{K}_{2} \mathrm{~B}_{4} \mathrm{O}_{7}$ solution $(3.5 \mathrm{ml}$.). Potassium periodate $(0 \cdot 1 \mathrm{M})$ in $0.2 \mathrm{~N} \cdot \mathrm{KOH}(0.625 \mathrm{ml}$.) was then added. After $8 \mathrm{~min} . \mathrm{KBH}_{4}(16 \mathrm{mg}$.) was added with continuous stirring. Three minutes later acetic acid $(0.2 \mathrm{ml}$.) was added dropwise. The mixture was stirred for $30 \mathrm{~min} ., \mathrm{M}-\mathrm{NaCl}(0 \cdot 7 \mathrm{ml}$.) was then added and $\mathrm{Na}^{+}$ions were removed on a $5 \cdot 1 \mathrm{~cm} . \times 0 \cdot 7 \mathrm{~cm}$. column of Dowex $50 \times 16$ cation-exchange resin. Anions present in the effluent were exchanged for acetate by passage through a $10 \mathrm{~cm} . \times 0.7 \mathrm{~cm}$. column of Dowex $2 \times 8$ acetate. The combined effluent and washings were stirred for $20 \mathrm{hr}$. with oxycellulose $(50 \mathrm{mg}$.) which had been previously washed with $0 \cdot 1 \mathrm{~N}$-acetic acid. The oxidized corticotropin was eluted from the oxycellulose with $0 \cdot 1 \mathrm{~N}$ $\mathrm{HCl}(2 \mathrm{ml}$.) followed by two washings (1 ml. each). The combined eluate and washings were freed from $\mathrm{Cl}^{-}$ions by exchange with acetate from Dowex $2 \times 8$ exchange resin and freeze-dried. Yield, 5.2 mg.; potency, 8 i.u./mg. (Table 2, Expt. 5).

Ascorbic acid, ferrous sulphate and oxygen (cf. Udenfriend, Clark, Axelrod \& Brodie, 1954). Oxycellulose-purified corticotropin (1 mg.) was treated with $0.1 \mathrm{ml}$. of a solution containing ascorbic acid $\left(25 \mathrm{mg}\right.$.), $\mathrm{FeSO}_{4}(42 \mathrm{mg}$.) and ethylenediaminetetra-acetic acid (25 mg.) in water
( $3 \mathrm{ml}$.), and the $\mathrm{pH}$ adjusted to 5.5 with $\mathrm{Na}_{2} \mathrm{HPO}_{4}$ solution. The mixture was shaken in contact with air for $2 \mathrm{hr}$. and the reaction terminated by the addition of $0 \cdot 1 \mathrm{~N}$-acetic acid $(1 \mathrm{ml}$.). All anions present in the solution were exchanged for acetate in Amberlite IRA-400 acetate. Portions of the eluate were taken for direct bioassay and for bioassay after reduction with cysteine hydrochloride (20 mg.) at $78^{\circ}$ for $18 \mathrm{hr}$. (Table 2, Expt. 6).

Photochemical oxidation (cf. Weil, Gordon \& Buchert, 1951). Corticotropin $A_{1}$ (2 mg.) was dissolved in water $\left(1.9 \mathrm{ml}\right.$.) containing $\mathrm{NaHCO}_{3}$ (2.5 mg.) and methylene blue $(0.1 \mathrm{mg}$.). The tube containing the mixture was cooled by a continuous flow of tap water. Irradiation was carried out with a bank of three $100 \mathrm{w}$ electric-light lamps, the centre lamp being placed $15 \mathrm{~cm}$. from the sample tube. Samples $(0.6 \mathrm{ml}$. each $)$ were withdrawn at 10,30 and $60 \mathrm{~min}$. Hydrochloric acid (, $0.035 \mathrm{ml}$.) and Dowex $50 \times 16$ ( $\mathrm{H}$ form; $50 \mathrm{mg}$.) were added to each sample, which was shaken mechanically for $15 \mathrm{~min}$. This procedure removed $\mathrm{Na}^{+}$ions and methylene blue. The ion-exchange resin was removed by centrifuging, and a portion $(0.05 \mathrm{ml}$.) of the supernatant liquid diluted for bioassay. The biological potencies of the products are given in Table 2 (Expt. 7).

A volume $(0.5 \mathrm{ml}$.) of the remainder of each sample was evaporated to dryness in vacuo and hydrolysed by heating with $6 \mathrm{~N}-\mathrm{HCl}(0.2 \mathrm{ml}$.) in a sealed capillary at $110^{\circ}$ for $18 \mathrm{hr}$. The hydrolysates were freed from most of the $\mathrm{HCl}$ by repeated evaporation with water in vacuo. The samples, together with a hydrolysate of corticotropin $\mathbf{A}_{1}$ prepared similarly, were subjected to paper electrophoresis in phosphate buffer $(0.066 \mathrm{M}, \mathrm{pH} 5.9)$ at a potential gradient of $2 \cdot 4 \mathrm{v} / \mathrm{cm}$. for $17 \mathrm{hr}$. The positions of the histidine zones were determined on a reference strip by development with the diazotized $p$-anisidine reagent of Sanger \& Tuppy (1951). The corresponding areas for the hydrolysates were cut out and the histidine was eluted with $0.1 \mathrm{~N}-\mathrm{HCl}$ ( $2 \mathrm{ml}$.). The histidine contents were determined by the colorimetric procedure of MacPherson (1942), light absorption being measured at $530 \mathrm{~m} \mu$ in $2 \mathrm{~cm}$. cells. This procedure provides a convenient method for the determination of histidine in protein hydrolysates in the range of $2-10 \mu \mathrm{g}$. The amounts found were: original material, $3.3 \%$ of histidine; 10 min. oxidation, $0.7 \%$; 30 min., $0.6 \%$; 60 min., $0.5 \%$.

\section{Reduction of peroxide-oxidized corticotropin $A_{1}$}

Thiol compounds at $78^{\circ}$. Oxidized corticotropin $\mathrm{A}_{1}$ $(0.23 \mathrm{mg}$.) was dissolved in $2 \mathrm{~N}$-acetic acid $(0.92 \mathrm{ml}$.). A volume $(0.2 \mathrm{ml}$.) of this solution was diluted for direct bioassay. (a) $0.2 \mathrm{ml}$. was diluted to $1 \mathrm{ml}$. with water, cysteine hydrochloride $(20 \mathrm{mg}$.) was 
added and the mixture maintained at $78^{\circ}$ for $18 \mathrm{hr}$. The solution was then diluted for bioassay. (b) $0.2 \mathrm{ml}$. was mixed with $0.8 \mathrm{ml}$. of a solution of cysteine acetate prepared by anion exchange from a solution of cysteine hydrochloride $(25 \mathrm{mg} . / \mathrm{ml}$.). The mixture was kept at $78^{\circ}$ for $18 \mathrm{hr}$. and diluted for bioassay. (c) $0.2 \mathrm{ml}$. was mixed with thioglycollic acid $(0.02 \mathrm{ml} ., 26.5 \mathrm{mg}$.), diluted to $1 \mathrm{ml}$. and the $\mathrm{pH}$ adjusted to $2 \cdot 5$. The mixture was heated at $78^{\circ}$ for $18 \mathrm{hr}$. and diluted for bioassay (Table 3 , Expt. 8).

Other reducing agents at $37^{\circ}$. Oxycellulosepurified corticotropin $(2.5 \mathrm{mg}$.) in $0.004 \mathrm{~N}$-acetic acid $\left(2.5 \mathrm{ml}\right.$.) was oxidized with $\mathrm{H}_{2} \mathrm{O}_{2}$ and the solution freed from excess of $\mathrm{H}_{2} \mathrm{O}_{2}$ as described above. (a) $0.5 \mathrm{ml}$. was diluted to $1 \mathrm{ml}$. and the $\mathrm{pH}$ adjusted to 6.0. 2:3-Dimercaptopropanol $(0.02 \mathrm{ml}$.) was added and the mixture kept at $37^{\circ}$. Samples for bioassay were removed at 41 and $90 \mathrm{hr}$. (b) $0.5 \mathrm{ml}$. was mixed with thioglycollic acid $(0.02 \mathrm{ml}$., $15 \mathrm{mg}$.) and water $(0.5 \mathrm{ml}$.). The mixture was kept at $37^{\circ}$ and samples were removed at 41 and $90 \mathrm{hr}$. (c) $0.5 \mathrm{ml}$. was diluted to $1 \mathrm{ml}$. and cysteine hydrochloride $(20 \mathrm{mg}$.) added. Portions were taken for bioassay after incubation for 41 and $90 \mathrm{hr}$. at $37^{\circ}$. (d) $0.5 \mathrm{ml}$. was diluted to $1 \mathrm{ml}$. and ascorbic acid (20 mg.) added. The mixture was kept at $37^{\circ}$, samples for bioassay being taken at 41 and $90 \mathrm{hr}$. Assay results are given in Table 3 (Expt. 9).

Potassium borohydride. Peroxide-oxidized corticotropin (OC purified; $2.2 \mathrm{mg}$.) was dissolved in water $(2 \mathrm{ml}$.$) and \mathrm{KBH}_{4}(20 \mathrm{mg}$.) added. The mixture was kept at $37^{\circ}$, portions for bioassay being taken at 30,60 and $120 \mathrm{~min}$. These were acidified with acetic acid before dilution (Table 3, Expt. 10).

Methionine. Corticotropin $\mathrm{A}_{1}$ (1 mg.) was dissolved in $0 \cdot 1 \mathrm{M}-\mathrm{NaHCO}_{3}$ and oxidized by the addition of $6 \% \mathrm{H}_{2} \mathrm{O}_{2}(3 \times 0.01 \mathrm{ml}$.). The reaction was terminated by the addition of $2 \mathrm{~N}$-acetic acid (1 ml.) and excess of $\mathrm{H}_{2} \mathrm{O}_{2}$ decomposed by shaking with platinum black. After separation from the platinum a portion was taken for direct bioassay. A volume (1 ml.) of the solution was treated with methionine (20 mg.) and maintained at $75^{\circ}$ for $18 \mathrm{hr}$. A portion of the mixture was diluted for bioassay (Table 3, Expt. 11).

\section{Treatment of corticotropin $A_{1}$ with sodium p-chloromercuribenzoate}

Corticotropin $A_{1}(0.22 \mathrm{mg}$.) was dissolved in water ( $1 \mathrm{ml}$.) and sodium $p$-chloromercuribenzoate (0.5 mg.) added. The mixture was shaken mechanically for $1 \mathrm{hr}$. and diluted to $4.4 \mathrm{ml}$. with $0.1 \mathrm{~N}$ acetic acid. This solution was further diluted for bioassay (Table 4, Expt. 12a).

Oxidation-reduction of corticotropin $A_{1}$ after treatment with sodium $\mathrm{p}$-chloromercuribenzoate

Corticotropin $A_{1}(0.44 \mathrm{mg}$.) was dissolved in $0.02 \mathrm{M}$-phosphate buffer, pH $7.5 \quad(2.2 \mathrm{ml}$.) and $0.2 \mathrm{ml}$. was withdrawn for bioassay. The remainder of the solution was shaken with sodium $p$-chloromercuribenzoate $(0.2 \mathrm{mg}$.) for $10 \mathrm{~min}$. Oxidation was carried out as described earlier with $3 \times 0.02 \mathrm{ml}$. of $6 \%(w / v) \mathrm{H}_{2} \mathrm{O}_{2}$ for $45 \mathrm{~min}$., the reaction being terminated by the addition of $0.1 \mathrm{~N}$-acetic acid (2 ml.). Excess of $\mathrm{H}_{2} \mathrm{O}_{2}$ was decomposed with platinum black and, after centrifuging, the solution was passed through a $1 \mathrm{~cm} . \times 0.7 \mathrm{~cm}$. column of Dowex $2 \times 8$ acetate. The filtrate and column washings were diluted to $8 \mathrm{ml}$. with water. A portion of this solution was taken for direct bioassay, $2 \mathrm{ml}$. was treated with cysteine hydrochloride (40 mg.) for $18 \mathrm{hr}$. at $78^{\circ}$ and finally diluted for bioassay. The results are given in Table 4 (Expt. 12b).

\section{Raney-nickel desulphurization of corticotropin $A_{1}$}

Corticotropin $A_{1}(2 \cdot 2 \mathrm{mg}$.) was dissolved in a mixture of $0.1 \mathrm{~N}$-acetic acid $(0.4 \mathrm{ml}$.) and ethylene glycol monomethyl ether (purified by distillation

Table 3. Reduction of oxidized corticotropin

$\begin{array}{cc} & \begin{array}{c}\text { Initial potency of } \\ \text { corticotropin } \\ \text { preparation }\end{array} \\ \text { Expt. } & \text { (i.u./mg.) } \\ \text { no. } & A_{1} 116(75-179) \\ 8 & \end{array}$

$9 \quad$ OC $53(33-85)$
OC, Oxycellulose concentrate; $A_{1}$, corticotropin $A_{1}$.

$$
\begin{aligned}
& \text { Potency after } \\
& \text { oxidation } \\
& \text { (\% of initial) } \\
& 24(\mathbf{1 6}-39)
\end{aligned}
$$

$11(5-20)$
Reducing conditions

(a) $2 \%$ Cysteine hydrochloride (18 hr.; $75^{\circ}$ )

(b) $2 \%$ Cysteine acetate $\left(18 \mathrm{hr}\right.$; $\left.75^{\circ}\right)$

(c) $2 \%$ Thioglycollic acid (buffered to pH $2 \cdot 5 ; 18 \mathrm{hr} . ; 7^{\circ}$ )

(a) $2 \%$ 2:3-Dimercaptopropanol ( $\mathrm{pH} 6 \cdot 0$; $90 \mathrm{hr}$; $37^{\circ}$ )

(b) $2 \%$ Thioglycollic acid $\left(90 \mathrm{hr}\right.$; $\left.37^{\circ}\right)$

(c) $2 \%$ Cysteine hydrochloride $\left(90 \mathrm{hr}\right.$; $\left.37^{\circ}\right)$

(d) $2 \%$ Ascorbic acid $\left(90 \mathrm{hr}\right.$.; $\left.37^{\circ}\right)$

$1 \% \mathrm{KBH}_{4}\left(30 \mathrm{~min} . ; 25^{\circ}\right)$

$2 \%$ Methionine (pH 3.0; $18 \mathrm{hr} . ; 7^{\circ}$ )
Reduced potency (\% of initial)

75 (47-132)

$108(72-165)$

$112(47-182)$

87 (68-110)

70 (55-87)

$102(49-188)$

$30(26-34)$

26 (18-49)

27 (21-36) 
from $\mathrm{SnCl}_{2} ; 2 \mathrm{ml}$.). Raney nickel (approx. $50 \mathrm{mg}$.) was added and the tube shaken to give a uniform suspension. Air was displaced from the tube and solution by repeated evacuation and admission of $\mathrm{H}_{2}$. The stoppered tube was maintained at $87-90^{\circ}$ for $7 \mathrm{hr}$. with continuous agitation. The mixture was then cooled, the nickel separated by centrifuging, and the supernatant liquid evaporated in vacuo to a volume of approximately $0.2 \mathrm{ml}$. The Raney nickel was washed three times with $2 \mathrm{ml}$. portions of $0.01 \mathrm{~N}$-acetic acid by vigorous shaking for 3-5 min. The washings were combined with the concentrated supernatant liquid and a freshly prepared solution of cysteine acetate was added to bring the solution to a concentration of $20 \mathrm{mg} . / \mathrm{ml}$. The mixture was maintained at $78^{\circ}$ for $18 \mathrm{hr}$. and the corticotropin adsorbed on to acid-washed oxycellulose (10 mg.). Corticotropin was eluted from the oxycellulose with $0 \cdot 1 \mathrm{~N}-\mathrm{HCl}(2 \mathrm{ml}),. \mathrm{Cl}^{-}$ions were exchanged for acetate with Dowex $2 \times 8$ acetate, and the solution was freeze-dried. Yield, $1.5 \mathrm{mg}$. The methionine content of the desulphurized and original materials were determined on $\mathrm{HCl}$ hydrolysates by quantitative paper chromatography. The values obtained were: corticotropin $\mathbf{A}_{1}$ (preparation 43/3) methionine, 2.8\%; Raneynickel-treated corticotropin $A_{1}(43 / 3)$, less than $0.5 \%$.

\section{Oxidation and reduction of corticotropin $A_{1}$ treated with Raney nickel}

Raney-nickel-treated corticotropin $A_{1}(0.09 \mathrm{mg}$.; methionine content less than $0.7 \%$ ) was dissolved in $0.01 \mathrm{M}-\mathrm{NaHCO}_{3}(0.4 \mathrm{ml}$.). Oxidation was carried

Table 4. Reactions of corticotropins

OC, Oxycellulose concentrate; $A_{1}$, corticotropin, $A_{1}$.

$\begin{array}{cc}\begin{array}{c}\text { Expt. } \\ \text { no. }\end{array} & \begin{array}{c}\text { corticotropin } \\ \text { preparation } \\ \text { (i.u./mg.) }\end{array} \\ 12 a & A_{1} 120(84-176) \\ & \\ 12 b & A_{1} 72(50-103) \\ & \\ 13 a & A_{1} 81(78-85) \\ 13 b & A_{1} \text { Desulphurized } \\ & \text { as above } \\ 14 a & A_{1} 116(75-179) \\ 14 b & \text { Oxidized } A_{1} \\ & 26(10-68) \\ 15 a & \text { OC } 42(28-62) \\ & \\ 15 b & \text { Oxidized OC } \\ & 12(8-19) \\ 16 a & \text { OC 42 (28-62) } \\ & \\ 16 b & \text { Oxidized OC } \\ & 12(8-19) \\ 17 a & A_{1} 116(75-179) \\ 17 b & \text { Oxidized } A_{1} \\ & 14(8-30) \\ 18 a & A_{1} 92(73-115) \\ 18 b & \text { Oxidized } A_{1} \\ & 10(5-17) \\ 19 a & A_{1} 92(73-115) \\ 19 b & \text { Iodinated } A_{1} \\ 20 a & \text { OC 32 (22-49) } \\ 20 b & \text { OC 32 (22-49) } \\ & \\ 20 c & \text { Oxidized OC } \\ & 10(8-14) \\ 21 a & A_{1} 116(75-179) \\ 21 b & \text { Oxidized } A_{1} \\ & 40(29-55) \\ & \\ & \\ & \end{array}$

\section{of}

Initial potency of potropin (i.u./mg.) A 120 (84-176)
$p$-Chloromercuribenzoate (60 min.; $25^{\circ}$ )

Reaction

$p$-Chloromercuribenzoate ( 60 min.; $25^{\circ}$; oxidized $\mathrm{H}_{2} \mathrm{O}_{2}$ )

Raney nickel (7 hr.; 90 $\left.{ }^{\circ}\right)$

Oxidized $\mathrm{H}_{2} \mathrm{O}_{2}$

Dimedon (pH 4.6; $3 \mathrm{hr}$.; $25^{\circ}$ )

Dimedon (pH 4.6; $3 \mathrm{hr}$; $25^{\circ}$ )

2:4-Dinitrophenylhydrazine in $\mathbf{9 9} \%$ acetic acid (10 min.; $\left.70^{\circ}\right)$

2:4-Dinitrophenylhydrazine in $99 \%$ acetic acid (10 min.; $70^{\circ}$ )

$1 \%$ Thiosemicarbazide in $0.1 \mathrm{~N}$ acetic acid $\left(6 \mathrm{hr}\right.$.; $\left.25^{\circ}\right)$

$1 \%$ Thiosemicarbazide in $0.1 \mathrm{~N}$ acetic acid $\left(6 \mathrm{hr} . ; 5^{\circ}\right)$

$0 \cdot 1 \mathrm{~N}-\mathrm{NaOH}\left(2 \mathrm{~min} . ; 25^{\circ}\right)$

$0 \cdot 1 \mathrm{~N}-\mathrm{NaOH}$ (2 min.; $25^{\circ}$ )

$\mathrm{NaCN}$ (pH 3.0; 30 min.)

$\mathrm{I}_{\mathbf{2}}$ (pH 6.5; $30 \mathrm{~min}$.)

$\mathrm{H}_{2} \mathrm{O}_{2}(\mathrm{pH} \mathrm{7 \cdot 0)}$

$5 \mathrm{~N}-\mathrm{HCl}$ (25 min.; $25^{\circ}$ )

$4 \%$ Dimethylaminobenzaldehyde in $5 \mathrm{~N}-\mathrm{HCl}\left(25 \mathrm{~min}\right.$; $2^{\circ}$ )

4\% Dimethylaminobenzaldehyde in $5 \mathrm{~N}-\mathrm{HCl}\left(25 \mathrm{~min} . ; 25^{\circ}\right)$

$0.03 \mathrm{~N}-\mathrm{HCl}\left(18 \mathrm{hr} . ; 8^{\circ}\right)$

\section{Potency}

(\% of initial)

87 (57-133)

38 (24-63)

89 (42-185)

$<12$

99 (53-182)

$121(70-210)$

$115(85-164)$

$52(36-76)$

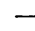

$81(62-110)$

$100(41-226)$

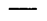

95 (64-131)

122 (72-216)

113 (65-194)
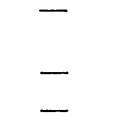

112 (71-178)

of $18 a$

22 (21-24)

5 (6-7)

81 (47-141)

$<10$

$58(51-64)$

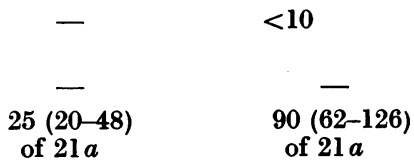


out with $6 \%(\mathrm{w} / \mathrm{v}) \mathrm{H}_{2} \mathrm{O}_{2}(3 \times 0.01 \mathrm{ml}$.) during $45 \mathrm{~min}$. The reaction was terminated by the addition of $2 \mathrm{M}$-acetic acid ( $1.4 \mathrm{ml}$.) and excess of $\mathrm{H}_{2} \mathrm{O}_{2}$ destroyed by shaking with platinum black. After removal of the platinum by centrifuging, a portion of the solution was removed for direct assay, and $1 \mathrm{ml}$. was reduced with cysteine hydrochloride $(20 \mathrm{mg}$.) at $78^{\circ}$ for $18 \mathrm{hr}$. before bioassay. The results of this experiment, together with the bioassay of the desulphurized corticotropin $A_{1}$, are given in Table 4, Expt. $13 a$ and $b$.

\section{Effect of various reagents on corticotropin $A_{1}$ and peroxide-oxidized corticotropin}

Dimedone. Solutions of corticotropin $\mathrm{A}_{\mathbf{1}}(0.26 \mathrm{mg}$.) and oxidized corticotropin $A_{1}(0.25 \mathrm{mg}$.) were prepared in $0.05 \mathrm{M}$-acetate buffer, $\mathrm{pH} 4.6(0.9 \mathrm{ml}$.). A $1 \%(w / v)$ ethanolic solution of dimedone (5:5dimethylcyclohexane-1:3-dione; $0.1 \mathrm{ml}$.) was added to each solution, and the mixtures were kept at room temperature for $3 \mathrm{hr}$. Acetic acid $(0.5 \mathrm{~N}, 1 \mathrm{ml}$.) was then added to each. A volume (1 ml.) of the oxidized corticotropin alution was reduced with cysteine hydrochloride $\left(20 \mathrm{mg}\right.$.) at $78^{\circ}$ for $18 \mathrm{hr}$. Portions of both solutions were diluted for bioassay (Table 4, Expt. 14).

2:4-Dinitrophenylhydrazine. Oxycellulose-purified corticotropin $(0.5 \mathrm{mg}$.) and a peroxide-oxidized corticotropin made from the same preparation $(0.5 \mathrm{mg}$.) were each dissolved in a saturated solution of 2:4-dinitrophenylhydrazine in $99 \%(\mathrm{v} / \mathrm{v})$ acetic acid $\left(0.1 \mathrm{ml}\right.$.). The mixtures were kept at $70^{\circ}$ for $10 \mathrm{~min}$. and diluted with water to $1 \mathrm{ml}$. Excess of 2:4-dinitrophenylhydrazine was removed from each solution by passage through $3.5 \mathrm{~cm} . \times 0.7 \mathrm{~cm}$. columns of Amberlite IR-100 cation-exchange resin (H form) and the columns were washed with $0 \cdot 1 \mathrm{~N}$-acetic acid $(3 \mathrm{ml}$.). Eluates and washings from each column were combined. A volume (1 ml.) of the oxidized corticotropin solution was reduced with cysteine hydrochloride $\left(20 \mathrm{mg}\right.$.) at $78^{\circ}$ for $18 \mathrm{hr}$. before bioassay (Table 4, Expt. 15).

Thiosemicarbazide. Oxycellulose-purified corticotropin (1 mg.) and a corresponding oxidized preparation ( $1 \mathrm{mg}$.) were dissolved in $0.1 \mathrm{~N}$-acetic acid $(1 \mathrm{ml}$.) and thiosemicarbazide $(10 \mathrm{mg}$.) was added to each solution. The mixtures were kept for $6 \mathrm{hr}$. at room temperature, excess of thiosemicarbazide was removed by means of short columns of Amberlite IR-100 cation-exchange resin ( $\mathrm{H}$ form; 0.5 g.) and the columns were washed with $0.05 \mathrm{~N}-\mathrm{HCl}$ $(2 \mathrm{ml}$.). Both solutions were diluted with water to $6.3 \mathrm{ml}$. and the oxidized corticotropin solution was reduced with cysteine hydrochloride $(20 \mathrm{mg}$.) at $78^{\circ}$ for $18 \mathrm{hr}$. before bioassay (Table 4, Expt. 16).

Alkali. Corticotropin $\mathbf{A}_{1}(0.33 \mathrm{mg}$.) and the corresponding peroxide-oxidized corticotropin $\mathbf{A}_{1}$ $(0.3 \mathrm{mg}$.) were dissolved separately in water
(1.4 ml. portions), and $\mathrm{N}-\mathrm{NaOH}(0.1 \mathrm{ml}$.) was added to each solution. The ultraviolet absorption at $275 \mathrm{~m} \mu$ was measured 30,60 and 120 sec. after the addition of alkali. Acetic acid $(2 \mathrm{~N}, 0.5 \mathrm{ml}$.) was added to both solutions after $2 \mathrm{~min}$. in order to terminate the reaction. Portions of each solution were reduced with cysteine hydrochloride $(20 \mathrm{mg}$.) at $78^{\circ}$ for $18 \mathrm{hr}$. and diluted for bioassay (Table 4, Expt. 17). No change in the optical density at $275 \mathrm{~m} \mu$ was observed during the experimental period with either solution.

Acid. Peroxide-oxidized corticotropin $\mathbf{A}_{1}$ $\left(0.39 \mathrm{mg}\right.$.) in $0.03 \mathrm{~N}-\mathrm{HCl}\left(2 \mathrm{ml}\right.$.) was heated at $78^{\circ}$ for $18 \mathrm{hr}$. After cooling, $1 \mathrm{ml}$. was diluted for direct bioassay and the remainder was reduced with cysteine hydrochloride $\left(20 \mathrm{mg}\right.$.) at $78^{\circ}$ for $18 \mathrm{hr}$. before dilution for bioassay (Table 4, Expt. 21).

Cyanide. Peroxide-oxidized corticotropin $\mathbf{A}_{1}$ $(0.53 \mathrm{mg}$.) in $0.1 \mathrm{~N}$-acetic acid $(1.5 \mathrm{ml}$.) was treated with $\mathrm{NaCN}$ (1 mg.). After $30 \mathrm{~min}$. $\mathrm{CN}^{-}$ions were removed by exchange on Dowex $2 \times 8$ acetate (approx. $10 \mathrm{mg}$.). A portion of the solution was diluted for direct bioassay and a further $1 \mathrm{ml}$. portion reduced with cysteine hydrochloride (20 mg.) at $78^{\circ}$ for $18 \mathrm{hr}$. A portion of the oxidized corticotropin $A_{1}$ was reduced under identical conditions for comparison (Table 4, Expt. 18).

p-Dimethylaminobenzaldehyde. Oxycellulose-purified corticotropin ( $2 \mathrm{mg}$.) and a corresponding peroxide-oxidized preparation (2 mg.) were each dissolved in $5 \mathrm{~N}-\mathrm{HCl}(0.05 \mathrm{ml}$.) and a $4 \%(\mathrm{w} / \mathrm{v})$ solution of $p$-dimethylaminobenzaldehyde in $5 \mathrm{~N}$ $\mathrm{HCl}(0.05 \mathrm{ml}$.) was added to each solution. The mixtures were kept at room temperature for $25 \mathrm{~min}$. and water $(1.4 \mathrm{ml}$.) was finally added to each. The absorption spectra of both solutions were measured at wavelengths from 530 to $640 \mathrm{~m} \mu$ at $10 \mathrm{~m} \mu$ intervals. No qualitative or quantitative differences were observed in the spectra (absorption maxima at 540 and $580 \mathrm{~m} \mu$ ). Portions of each reaction mixture were diluted for bioassay. A portion of the oxidized corticotropin reaction mixture was reduced with cysteine hydrochloride (20 mg. $/ \mathrm{ml}$.) at $78^{\circ}$ for $18 \mathrm{hr}$. and diluted for bioassay. A control experiment was carried out with oxycellulose-purified corticotropin (2 mg.) in $5 \mathrm{~N}-\mathrm{HCl}(0.05 \mathrm{ml}$.). This solution was kept at room temperature for 25 min., neutralized and diluted for bioassay (Table 4, Expt. 20).

\section{Iodination and oxidation of corticotropin $A_{1}$}

Corticotropin $A_{1}(1.1 \mathrm{mg}$.$) in 0.05 \mathrm{M}$-acetate buffer, pH 6.5 (0.7 ml.), was treated with $0.01 \mathrm{~N}-\mathrm{I}_{2}$ solution $(0.2 \mathrm{ml}$.), equivalent to 6 atoms of $\mathrm{I} /$ tyrosine residue, calculated on a tyrosine content of $6 \cdot 2 \%$. The mixture was kept at room temperature for $30 \mathrm{~min}$. Measurement of the ultraviolet absorption at $312 \mathrm{~m} \mu$ indicated that $81 \%$ of the 
tyrosine was converted into 3:5-di-iodotyrosine. During the reaction period a small amount of precipitate formed. This was redissolved finally by the addition of $2 \mathrm{~N}$-acetic acid $(0.5 \mathrm{ml}$.) to the mixture. Sodium thiosulphate $(0.01 \mathrm{~N}, 0.2 \mathrm{ml}$.) was then added to remove excess of $I_{2}$ and anions in the mixture were exchanged for acetate by passage of the solution through a short column of Dowex $2 \times 8$ acetate. Eluate and column washings amounted to $2.9 \mathrm{ml}$.; $0.9 \mathrm{ml}$. of this solution was diluted for direct bioassay. Another portion (1 ml.) was adjusted to $\mathrm{pH} 7.0$ and oxidized with $6 \%(\mathrm{w} / \mathrm{v})$ $\mathrm{H}_{2} \mathrm{O}_{2}\left(3 \times 0.01 \mathrm{ml}\right.$.). Excess of $\mathrm{H}_{2} \mathrm{O}_{2}$ was removed by shaking with platinum black. A portion of the separated supernatant liquid was diluted for bioassay, and a further portion reduced with cysteine hydrochloride $\left(20 \mathrm{mg} . / \mathrm{ml}\right.$.) at $75^{\circ}$ for $18 \mathrm{hr}$. before bioassay (Table 4, Expt. 19). Examination of the ultraviolet absorption of this solution at $312 \mathrm{~m} \mu$ indicated that the 3:5-di-iodotyrosine content was unchanged.

\section{DISCUSSION}

The evidence presented in the Experimental section makes it clear that the adrenal ascorbic aciddepleting potency of corticotropin preparations can be destroyed by oxidation with hydrogen peroxide or ferricyanide and that the biological activity of such materials can be quantitatively restored by treatment with thiols. Up to the present time, no reducing agent other than a thiol compound has been found to be effective in this reduction. Ascorbic acid, potassium borohydride, sodium thiosulphate, hydrogen and platinum, zinc and hydrochloric acid and electrolytic reduction are equally ineffective in restoring the biological activity of peroxideoxidized corticotropin. Since the publication of our preliminary communication, the peroxide oxidation and thiol reduction of corticotropin have been confirmed by Dixon \& Stack-Dunne (1955), who have also demonstrated differences in the chromatographic behaviour of the untreated and oxidized forms (see also Dixon, 1955, 1956). Farmer \& Morris (1956) have also been able to separate oxidized from unchanged corticotropin $A_{1}$ by chromatography on a column of carboxymethylcellulose. There is therefore no doubt that the oxidized form of corticotropin represents a chemically distinct species. The oxidation process appears to be pH dependent (Table 2), being more effective at alkaline than at acid $\mathrm{pH}$ values. On the alkaline side of neutrality, however, some irreversible oxidation may occur. On the other hand, reduction with thiols is more rapid at low $\mathrm{pH}$ values, although the $\mathrm{pH}$ effect is less marked than with the oxidation process.

In contrast to the action of hydrogen peroxide and ferricyanide, peroxydisulphate and periodate bring about irreversible inactivation. The periodate inactivation may be explained by the oxidation of the $N$-terminal serine residue in corticotropin, which other studies (White, 1955) have shown to be essential for the biological activity of the hormone.

The chemical nature of the oxidation-reduction centre in corticotropin is not readily explained by present knowledge of the structure of the hormone. Bell (1954) and Howard, Shepherd, Eigner, Davies $\&$ Bell (1955) determined the amino acid sequence of $\beta$-corticotropin, a highly purified and apparently homogeneous preparation obtained by counter. current distribution of oxycellulose concentrates of pig corticotropin. The structure proposed by these workers is a single chain of thirty-nine amino acid residues. Part of this chain may be removed by the action of pepsin without reduction in biological activity. The essential sequence is: Ser.Tyr.Ser. Met . Glu . His . Phe . Arg . Try . Gly . Lys . Pro . Val . Gly . Lys . Lys . Arg . Arg . Pro . Val . Lys . Val. Tyr.Pro.Asp.Gly.Ala.Glu. [For definitions of these abbreviations see Biochem. J. (1953), 55, 5.]

The amino acid composition of our preparation of corticotropin $A_{1}$ given in Table 5 is consistent with the structure proposed by Bell (1954) and differs only in a somewhat higher proline content.

Countercurrent studies kindly carried out by Dr P. H. Bell, with a similar preparation, showed that it contained $67 \%$ of $\beta$-corticotropin.

It may be concluded that the structure proposed for $\beta$-corticotropin by Howard et al. (1955) is also

Table 5. Amino acid composition of corticotropin $A_{1}$ and of peroxide-oxidized corticotropin $A_{1}$

\begin{tabular}{|c|c|c|c|c|}
\hline \multirow[b]{2}{*}{ Amino acid } & \multicolumn{2}{|c|}{ Corticotropin $\mathbf{A}_{1}$} & \multicolumn{2}{|c|}{ 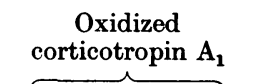 } \\
\hline & $\begin{array}{l}\text { Concn. } \\
\text { (g./100 g.) }\end{array}$ & $\begin{array}{l}\text { Minimum } \\
\text { no. of } \\
\text { residues }\end{array}$ & $\begin{array}{l}\text { Concn. } \\
\text { (g./100 g.) }\end{array}$ & $\begin{array}{l}\text { Minimum } \\
\text { no. of } \\
\text { residues }\end{array}$ \\
\hline Alanine & $4 \cdot 46$ & $2 \cdot 9$ & $4 \cdot 84$ & $3 \cdot 0$ \\
\hline Arginine & $8 \cdot 66$ & $2 \cdot 9$ & $9 \cdot 41$ & $3 \cdot 0$ \\
\hline Aspartic acid & $\mathbf{5} \cdot 57$ & $2 \cdot 4$ & $4 \cdot 97$ & $2 \cdot 0$ \\
\hline Glutamic acid & $13 \cdot 34$ & $5 \cdot 3$ & $14 \cdot 07$ & $5 \cdot 2$ \\
\hline Glycine & $4 \cdot 20$ & $\mathbf{3} \cdot \mathbf{3}$ & $4 \cdot 13$ & $\mathbf{3} \cdot \mathbf{0}$ \\
\hline Histidine & $2 \cdot 94$ & $1 \cdot 1$ & $3 \cdot 06$ & $1 \cdot 1$ \\
\hline Leucine & $\mathbf{4} \cdot 50$ & $2 \cdot 0$ & $5 \cdot 10$ & $2 \cdot 1$ \\
\hline Lysine & $14 \cdot 07$ & $5 \cdot 6$ & $13 \cdot 49$ & $5 \cdot 0$ \\
\hline Methionine & $2 \cdot 40$ & 0.9 & $2 \cdot 17$ & 0.8 \\
\hline Phenylalanine & 8.88 & $3 \cdot 1$ & $8 \cdot 52$ & $2 \cdot 8$ \\
\hline Proline & $12 \cdot 22$ & $6 \cdot 2$ & $10 \cdot 48$ & $5 \cdot 2$ \\
\hline Serine* & $\mathbf{3} \cdot \mathbf{3 0}$ & $1 \cdot \overline{8}$ & $3 \cdot 06$ & $1 \cdot 6$ \\
\hline Tryptophan $†$ & $4 \cdot 17$ & $1 \cdot 2$ & $3 \cdot 65$ & $1 \cdot 0$ \\
\hline Tyrosine & $6 \cdot 22$ & $2 \cdot 0$ & $6 \cdot 52$ & $2 \cdot 0$ \\
\hline Valine & $5 \cdot 32$ & $2 \cdot 6$ & $5 \cdot 33$ & $2 \cdot 5$ \\
\hline
\end{tabular}

* Corrected for destruction on hydrolysis.

$\dagger$ Calculated from ultraviolet absorption (Beaven \& Holiday, 1952). 
valid for the preparations of corticotropin $A_{1}$ used in the present studies.

Only five of the amino acids present in the essential sequence could conceivably be involved in a reversible oxidation-reduction system: serine, tyrosine, methionine, histidine and tryptophan. The presence in the hormone molecule of a sulphydryl-disulphide system which has hitherto escaped detection is excluded by the failure of $p$-chloromercuribenzoate to prevent oxidation and subsequent reduction (Table 4, Expt. 12), and by the fact that desulphurization with Raney nickel under very vigorous conditions also does not affect the oxidation-reduction process (Table 4, Expt. 13). The latter finding also excludes methionine, as the analytical results show that the single residue of this amino acid in the hormone molecule can be completely desulphurized without change in the biological potency of corticotropin $A_{1}$ and without impairing the ability to undergo reversible oxidation-reduction. It is interesting that the methionine contents of untreated and oxidized hormones given in Table 5 indicate that this amino acid is not converted into the sulphone or sulphoxide during the oxidation process.

Expts. 14, 15, 16 and 18 (Table 4) were designed to test the possibility that a carbonyl compound was formed on oxidation. A somewhat unlikely possibility was that the primary alcoholic group of the $N$-terminal serine residue might be oxidized to an aldehyde group either directly or through a hydroperoxide. If a carbonyl group were present in the oxidized form, reaction with carbonyl reagents such as dimedone, 2:4-dinitrophenylhydrazine or thiosemicarbazide should prevent subsequent reduction with restoration of biological activity. Expts. 14, 16 and 18 with dimedone, thiosemicarbazide and cyanide ions show that this blocking does not occur. Expt. 15 is less conclusive, owing to the inactivating effect of 2:4-dinitrophenylhydrazine on corticotropin itself, but does confirm the absence of the blocking effect. These experiments, together with the unchanged serine contents shown in Table 5, eliminate the possibility of this amino acid being involved in the oxidation centre.

It has never been demonstrated that histidine can take part in a reversible oxidation-reduction system, although Weil \& Buchert (1951) have shown that it can be oxidized in intact proteins under relatively mild conditions. Photochemical oxidation at $\mathrm{pH} 8.3$ in air, with methylene blue as oxygen carrier, resulted in a progressive irreversible inactivation, which was, however, not parallel to the decrease in the histidine content (Table 2, Expt. 7). The fall in histidine content to $22 \%$ of the original value after photo-oxidation for $10 \mathrm{~min}$., without any significant alteration in biological activity, indicates that this amino acid, like methionine, is probably not essential for hormonal activity. This fact, together with the unchanged histidine content of the oxidized hormone, makes it very improbable although not impossible that histidine is involved in the oxidation-reduction centre. It is possible that histidine, although not essential for biological activity, may be modified in the oxidized form, but the chemical basis for this is not clear, especially as the modified form must be chromatographically indistinguishable from the parent amino acid. The irreversible inactivation after further photo-oxidation is probably due to destruction of the aromatic amino acids (Weil et al. 1951).

The oxidation of tyrosine in intact proteins or peptides has been demonstrated many times, although there is very little evidence that a reversible process can occur. In the present case, the stability of the oxidized form to $0 \cdot 1 \mathrm{~N}-\mathrm{NaOH}$ (Table 4, Expt. 17) makes it unlikely that the latter is a catechol derivative. This is confirmed by the apparent inability of the oxidized form to form an acidic boric acid complex. Hydroxylation by the method of Udenfriend et al. (1954), which specifically introduces hydroxyl groups into aromatic rings, results in irreversible inactivation of the hormone (Table 2, Expt. 6). This may, of course, be due to conversion of phenylalanine into tyrosine residues or hydroxylation of tryptophan in the hormone molecule.

Iodination of corticotropin $A_{1}$ (Table 4, Expt. 19) is more difficult to interpret. Iodination with 6 atoms of iodine/tyrosine residue at $\mathrm{pH} 6.5$ gives a reaction product which is less active than the starting material. This can be oxidized with hydrogen peroxide to an almost inactive product, which can in turn be reduced to give a biologically active material which is intermediate in activity between the original and the iodinated hormone. Iodination thus does not appear to eliminate the oxidation-reduction centre, although it does lead to some irreversible inactivation.

The evidence of these experiments, together with the unaltered ultraviolet absorption spectra of the oxidized form under both acid and alkaline conditions (Fig. 2) and the unchanged tyrosine content (Table 5), make it very unlikely that tyrosine is involved in the oxidation-reduction centre of corticotropin.

The evidence for tryptophan is less conclusive. It is clear from the identity of the ultravioletabsorption spectra of untreated and oxidized corticotropins that no extensive changes in the tryptophan molecule can occur. The tryptophan contents of the two preparations, estimated from the spectra by the method of Beaven \& Holiday (1952), are very similar, although that of the oxidized preparation is somewhat lower. 
Condensation of both untreated and oxidized preparations with $p$-dimethylaminobenzaldehyde in the presence of strong hydrochloric acid (Table 4, Expt. 20) leads to irreversible inactivation in both cases, indicating that the 2 position of the tryptophan residue is probably essential for biological activity, although the possibility of side reactions cannot be excluded. The identical absorption spectra of the coloured condensation products suggests that the 2 positions of the tryptophan residues are probably in similar states in both preparations and excludes a residue such as oxindolylalanine in the oxidized form. This conclusion is also supported by the ultraviolet-absorption spectra in alkaline solution (Cornforth, Dalgliesh \& Neuberger, 1951).

The oxidation products of tryptophan have attracted some attention in recent years because of their importance in the first stages of the metabolism of this amino acid. A number of possible hydroxylated or peroxide derivatives have been suggested [reviewed by Ek, Kissman, Patrick \& Witkop (1952) and by Dalgliesh (1955)] as the first products of the action of the enzyme tryptophan peroxidase on the amino acid. With the exception of oxindolyl.
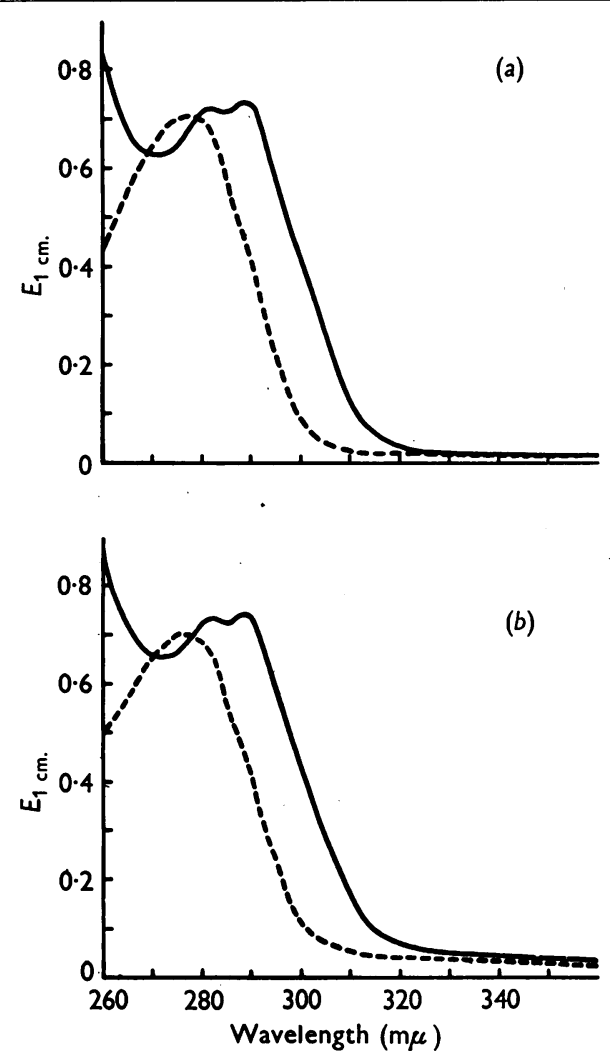

Fig. 2. Ultraviolet-absorption spectra of untreated $(a)$ and peroxide-oxidized corticotropin $(b)$.,$- 0 \cdot 1 \mathrm{~N}-\mathrm{NaOH}$; ...., $0.01 \mathrm{~N}-\mathrm{HCl}$. alanine none of these has been isolated or synthesized, so that their properties are unknown. The relatively high stability of oxidized corticotropin under acid (Table 4, Expt. 21) and alkaline conditions (Table 4, Expt. 17) makes its formulation as a hydroperoxide unlikely.

Houff, Hinsvark, Weller, Wittiver \& Sell (1954) have suggested that $N$-hydroxyindole derivatives are formed when certain indole compounds are oxidized with ferric chloride and perchloric acid. The indoles examined included several substituted carboxylic acids, but did not include tryptophan. Attempts to prepare similar $N_{1}$-hydroxy derivatives from tryptophan or acetyltryptophan in this laboratory have been unsuccessful. Houff et al. (1954) postulate a dimer as an intermediate in the formation of the $N$-hydroxyindoles, and it is possible that the formation of this compound is difficult with tryptophan or its peptides.

The experiments reported here, together with amino acid analyses presented in Table 5, make it improbable that any of these amino acids are concerned in the oxidation-reduction process. $\mathbf{A}$ possible exception is provided by histidine and by tryptophan, where the evidence is less conclusive and where a variety of oxidation products are theoretically possible.

Two alternatives remain: either the substance isolated as $\beta$-corticotropin is not in fact the biologically active hormone or the $\beta$-corticotropin molecule contains some hitherto unidentified group which determines the oxidation-reduction behaviour. The former alternative appears extremely unlikely in view of the impressive evidence of homogeneity presented by Bell (1954).

\section{SUMMARY}

1. The conditions for the oxidation of corticotropin to a biologically inactive product assayed by the adrenal ascorbic acid-depletion method, and for the reduction of this material with complete restoration of activity, have been investigated.

2. The nature of the groupings concerned in the oxidation-reduction process have been examined by studying the effect of various chemical treatments on this process.

3. Amino acid analyses of untreated and oxidized corticotropin $\mathbf{A}_{1}$ are presented.

4. The chemical nature of the oxidation-reduction centre is discussed. It is concluded that, with the possible exception of tryptophan, the oxidationreduction behaviour of the hormone cannot be accounted for by the amino acid residues known to be present in the corticotropin molecule.

The authors are indebted to Miss G. Atfield, who carried out the amino acid analyses by ion-exchange chromatography. 


\section{REFERENCES}

Astwood, E. B., Raben, M. S., Payne, R. W. \& Grady, A. B. (1951). J. Amer. chem. Soc. 73, 2969.

Beaven, G. H. \& Holiday, E. R. (1952). Advanc. Protein Chem. 7, 375.

Bell, P. H. (1954). J. Amer. chem. Soc. 76, 5565.

Cornforth, J. W., Dalgliesh, C. E. \& Neuberger, A. (1951). Biochem. J. 48, 598.

Cortis-Jones, B., Crooke, A. C., Henly, A. A., Morris, P. \& Morris, C. J. O. R. (1950). Biochem. J. 46, 173.

Dalgliesh, C. E. (1955). Advanc. Protein Chem. 10, 33.

Dedman, M. L., Farmer, T. H. \& Morris, C. J. O. R. (1955). Biochem. J. 59, xii.

Dedman, M. L., Farmer, T. H., Morris, P. \& Morris, C. J. O. R. (1952). Recent Progr. Hormone Res. 7, 59.

Dixon, H. B. F. (1955). Biochim. biophys. Acta, 18, 599.

Dixon, H. B. F. (1956). Biochem. J. 62, 25 P.

Dixon, H. B. F., Moore, S., Stack-Dunne, M. P. \& Young, F. G. (1951). Nature, Lond., 168, 1044.

Dixon, H. B. F. \& Stack-Dunne, M. P. (1955). Biochem. J. $61,483$.

Ek, A., Kissman, A., Patrick, J. B. \& Witkop, B. (1952). Experientia, 8, 36.

Farmer, T. H. \& Morris, C. J. O. R. (1956). Nature, Lond., $178,1465$.

Hirs, C. W. H., Moore, S. \& Stein, W. H. (1953). J. biol. Chem. 200, 493.
Houff, W. H., Hinsvark, O. N., Weller, L. E., Wittiver, S. H. \& Sell, H. M. (1954). J. Amer. chem. Soc. 76, 5654.

Howard, K. S., Shepherd, R. G., Eigner, E. A., Davies, D. S. \& Bell, P. H. (1955). J. Amer. chem. Soc. 77, 3419.

Kuehl, F. A., Meisinger, M. A. P., Brink, N. G. \& Folkers, K. (1953). J. Amer. chem. Soc. 75, 1955.

McFarren, E. F. (1951). Analyt. Chem. 23, 168.

MacPherson, H. T. (1942). Biochem. J. 36, 59.

Moore, S. \& Stein, W. H. (1951). J. biol. Chem. 192, 663.

Moore, S. \& Stein, W. H. (1954). J. biol. Chem. 211, 907.

Morris, C. J. O. R. (1951). Analyst, 76, 470.

Payne, R. W., Raben, M. S. \& Astwood, E. B. (1950). J. biol. Chem. 187, 719.

Pugsley, L. I. (1946). Endocrinology, 39, 161.

Sanger, F. \& Tuppy, H. (1951). Biochem. J. 49, 463.

Sayers, M. A., Sayers, G. \& Woodbury, L. A. (1948). Endocrinology, 42, 379.

Udenfriend, S., Clark, C. T., Axelrod, J. \& Brodie, B. B. (1954). J. biol. Chem. 208, 731 .

Wael, J. de \& Cadavieco, R. D. (1954). Rec. Trav. chim. Pays-Bas, 73, 333.

Weil, L. \& Buchert, A. R. (1951). Arch. Biochem. Biophys. 34, 1.

Weil, L., Gordon, W. G. \& Buchert, A. R. (1951). Arch. Biochem. Biophys. 33, 90.

White, W. F. (1955). J. Amer. chem. Soc. 77, 4691.

White, W. F. \& Fierce, W. L. (1953). J. Amer. chem. Soc. 75, 245.

\title{
The Estimation of Serum Protein-Bound Iodine by Alkaline Incineration
}

\author{
By J. D. ACLAND \\ Department of Pharmacology and Therapeutics, University of Sheffield, and Sheffield Royal Infirmary
}

(Received 14 September 1956)

The term 'protein-bound iodine' (PBI) is used to describe that fraction of blood iodine which is nondialysable and precipitates with serum or plasma proteins (Trevorrow, 1939). In the absence of structural damage to, or carcinoma of, the thyroid, about $75-100 \%$ of serum PBI consists of Lthyroxine, bound to protein, in a way as yet undefined, from which it can be released by denaturation. About $90 \%$ of the thyroxine is selectively combined with a 'thyroxine-binding-protein' fraction, intermediate in properties between $\alpha_{1}$ - and $\alpha_{2}$ globulins, while the remainder is associated with albumin (Taurog \& Chaikoff, 1948; Gordon, Gross, O'Connor \& Pitt-Rivers, 1952 ; Petermann, Robbins \& Hamilton, 1954; Robbins, Petermann \& Rall, 1955). Of the other physiologically active compounds secreted by the thyroid, 3:5:3'-tri-iodothyronine is bound to protein in a similar way to thyroxine, though less strongly (Deiss, Albright \& Larson, 1953), whereas no data are available for 3:3'-di-iodothyronine or for $3: 3^{\prime}: 5^{\prime}$-tri-iodothyronine (Roche, Michel, Wolf \& Nunez, 1956).

Salter \& McKay (1944) were the first workers to describe a method of estimating serum PBI, in which organic material was destroyed by alkaline incineration. Liberated iodide was then determined, after elution, by its catalytic effect on the reduction of ceric salts by arsenious acid (Sandell \& Kolthoff, 1937). This technique was subsequently modified by Barker \& co-workers (Barker \& Humphrey, 1950; Barker, Humphrey \& Soley, 1951). Brown, Reingold \& Samson (1953) and Grossmann \& Grossmann (1955) described further modifications, which were claimed to increase the accuracy of the method. Doubt was cast by some of these authors on certain aspects of the technique, different workers not being always in agreement about the efficiency of a particular step.

The present investigation was started with the dual object of resolving the contradictions between 